\title{
ГЕЛОТОФОБІЯ ЯК ПСИХОЛОГІЧНА ПРОБЛЕМА СУСПНЛЬСТВА ТА ФОРМА СОЦІОФОБІЇ (ОГЛЯД ЛІТЕРАТУРИ)
}

Київський національний університет ім. Тараса Шевченка

Резюме. У статті аналізується особлива форма соціофобії - гелотофобія (страх бути осміяним) - психічний розлад невротичного спектра за типом соціофобії. Встановлено, що емоційними патернами гелотофобії $\epsilon$ страх, тривога, сором, почуття провини тощо. Загальними показниками є: наявність вираженого страху певного типу соціальних ситуацій (ситуації глузування), переважання тривоги в певних ситуаціях, вираженість

Останнім часом науковий інтерес дедалі частіше зосереджується на вивченні та дослідженні негативної сторони впливу гумору на оточуючих. Психічний розлад, при якому людина боїться бути осміяною, називається гелотофобією. При дослідженні гелотофобії важливо також акцентувати увагу на специфічності іiі психофізіологічних проявів та впливу цих проявів на розвиток психічних розладів особистості. Саме розгляду цих та інших аспектів присвячена дана стаття.

Теоретико-методичною базою дослідження стали уявлення про гелотофобію як про форму соціофобії (Тітц, Форабоско, Рух); психологічна концепція гумору як прояв переваги і ворожості (Платон, Аристотель, Грунер, Зіліман, Гоббс); теорія Ріда Мартіна про негативні та позитивні стилі гумору залежно від мети використання гумору: подолання внутрішньоособистісних проблем суб'єкта або поліпшення взаємин з оточуючими; принципи вітчизняного клінікопсихологічного підходу до вивчення психічних розладів, заснованого на принципі синдромного аналізу (Зейгарник, Критська, Мелешко, Поляків, Соколова, Коченов, Ніколаєва); принципи вітчизняної психіатричної школи, які розглядають соціофобію як соціальний тривожний розлад, що представляє інвалідизуюче хронічне захворювання, що має чіткі критерії діагностики в міжнародній класифікації хвороб (Каплан, Смулевич, Тиганов, Монтгомері, Ковпак).

У контексті соціофобії гелотофобія є, насамперед, фобічним розладом, який пов'язаний із такими емоційними переживаннями, як сором, страх, тривога. Дуже часто агресивні методи гумору використовуються як примусу до певних дій. Сміючись над ким-небудь, людина висловлює несхвалення, провокує почуття провини або сорому. Якщо почуття провини стосується невідповідності вчинків стандартам або очікуванням, то сором торкається, насамперед, власне самосвідомості та самооцінки, і є в цьому сенсі більш болючим і деструктивним переживанням. Гідним уваги в цьому контексті можуть бути дослідження щодо того, яким чином люди справляються із насмішками оточуючих. Існує ряд особистостей, психофізіологічних симптомів тривоги, низька самооцінка і страх критики, емоційне переживання, усвідомлення того, що страх не обгрунтований, уникнення потенційно небезпечних ситуацій, що у своїх крайніх проявах призводить до соціальної ізоляції.

Ключові слова: гелотофобія, соціофобія, страх, невротична особистість.

які особливо бояться насмішок оточуючих. Дослідження демонструють низький поріг сорому в представників даної категорії, що є приводом для збентеження на разі гумору, сміху, посмішки незалежно від контексту [22, 29].

Таке явище, як патологічний страх здаватися смішним, вперше описано М. Тітцем й отримало назву «гелотофобія». Автор розглядав гелотофобію в контексті психопатології як особливу форму соціофобії [37].

Страх бути осміяним розглядався ще сто років тому французьким психіатром Павлом Гартенбергом у контексті соціальних страхів. Він описував таких людей, як боязких, із часто необгрунтованими проявами почуття ніяковості, сорому і страху, які в основному виникали в присутності інших людей. Подібні прояви супроводжувалися фізіологічними змінами (тремтіння, почервоніння, підвищене потовиділення тощо), порушеннями в роботі психічних функцій (уваги, мислення, пам'яті). Визначальною ознакою такого розладу автор вважав страх глузування, який був тісно пов'язаний зі страхом саморозкриття і страхом вираження власної думки $[9,33]$.

На сьогоднішній день дослідники описують людей, які мають страх бути осміяними як людей, які глибоко переконані в тому, що з ними щось не так, що оточуючі сприймають їх як дивакуватих та комічних. На думку М.Тітца, екстремальне вираження гелотофобії включає параноїдні тенденції, підвищену сенситивність і образливість i, як результат, - соціальну ізоляцію [37].

Серед особливостей гелотофобії $є$ такі, які нагадують опис критеріїв соціофобії у міжнародній класифікації хвороб. Загальними показниками є: наявність вираженого страху певного типу соціальних ситуацій (ситуації глузування), переважання тривоги в певних ситуаціях, вираженість психофізіологічних симптомів тривоги, низька самооцінка і страх критики, емоційне переживання, усвідомлення того, що страх не обгрунтований, уникнення потенційно небезпечних ситуацій, що у своїх крайніх проявах призводить до соціальної ізоляції $[4,18,40]$. Водночас можна відзначити ряд специфічних особливостей гело- 
тофобії. Д. Віл зауважує, що концепція соціофобіï має багато спільного із дослідженнями сорому, однак ці два напрямки досліджень не перетинаються в літературі [32]. Гелотофобія, як особлива форма тривожності, заснована на соромі, базується на переконанні людини у своїй комічності і безглуздості, в очікуванні того, що над нею будуть сміятися. Соціофобія, за визначенням MKX-10, DSM-IV, не включає дану характеристику. Теорії соціофобії фокусуються на особливому почутті, що людина зробила помилку, яку не можна простити або виправити [10, 21, 38]. Індивіди 3 вираженою гелотофобією уникають спілкування з іншими людьми, намагаються не потрапляти їм зайвий раз на очі, оскільки підозрюють, що інші постійно шукають у них докази їхньої безглуздості і дивакуватості. Таку особливість можна спостерігати і в людей з ознаками соціофобії, коли страх викликають соціальні ситуації, або які відчуваються із посиленою тривогою.

М. Тітц описує типову зовнішність осіб із вираженою гелотофобією: брак жвавості і спонтанності, веселощів часто виглядають дистантними і холодними по відношенню до однолітків [10, 20]. Нерідко розвивається загальне м'язове напруження як відображення емоційного дискомфорту, і психофізіологічні симптоми (підвищене серцебиття, тремор, почервоніння, сухість у роті та горлі, прискорене дихання, порушення мови). Усі ці прояви типові для соціофобії. Специфічним же фізіологічним симптомом, що відрізняє гелотофобію, $є$ заморожена експресивність, міміка. У ситуації гострої тривоги (тривоги сорому) лицьова експресія цих людей стає нерухомою і неживою, схожою на дерев'яну маску. Пацієнти починають надмірно контролювати рухи своїх рук i ніг, тому вони втрачають спонтанність. Таку специфічну «дерев'яну» зовнішність М. Тітц назвав «синдромом Піноккіо», і вона є однією 3 ключових ознак гелотофобії $[10,20]$.

Люди із вираженою гелотофобією не сприймають сміху і посмішки співрозмовника як щось позитивне, але оцінюють їх як знак глузування, образи, агресії. Вони переконані, що їх зовнішність або вчинки насправді смішні й безглузді, тобто сміх оточуючих над ними небезпідставний. «Люди, що мають страх бути осміяними сміються неохоче, проти волі, близько до серця сприймають гумористичні зауваження 3 боку інших людей, які можуть жартувати тільки в оточенні дуже близьких людей, сприймають доброзичливі жарти оточуючих як насмішку над собою. Їх сміх часто неприродний і недоречний, вони часто не розуміють сенсу жартів або розуміють неправильно. Гумор для них - це змагання, вони презирливі, сміються частіше «над іншими, ніж з іншими», не використовують почуття гумору як копінг-механізм. У цілому, вони сміються над усім і всіма, або не сміються зовсім. Таким людям найчастіше притаманні такі емоційні патерни поведінки, як страх, тривога, сором, почуття про- вини тощо. Розглянемо кожен $з$ означених емоційних патернів гелотофобії окремо $[17,35,39]$.

Тривога і страх $є$ неминучими супутниками людського життя, до певного моменту відіграють важливу пристосувальну роль, насамперед, виконують функцію попередження про можливу небезпеку, проте відрізняються в першому випадку реакцією на невідому, у другому - на відому небезпеку для людини. У багатьох випадках тривога може бути природною, адекватною і, навіть, корисною. Однак у центрі уваги цієї роботи знаходиться патологічна тривога, яка може набувати хронічного характеру і не піддається короткочасній психотерапії. Тривога $є$ емоційним станом, за яким стоїть очікування чогось невизначеного, негативного або небезпечного. На відміну від страху, тривога являє собою розпливчастий, тривалий і невиразний страх із приводу майбутніх подій. Як підкреслював 3. Фрейд, тривога на протилежність страху заснована на почутті безпорадності або перед зовні зумовленими чинниками, або перед внутрішніми (наприклад, боягузтво). Вона виникає в ситуаціях, коли ще немає (i не може бути) реальної небезпеки для людини, але вона чекає іiі, причому поки не уявляє як із нею впоратися. Тривога викликається такою небезпекою, яка загрожує самій суті або самому ядру особистості. Тривога знаходиться в тісному зв'язку із фізіологічними процесами: супроводжується прискореним серцебиттям, підвищеним артеріальним тиском, нудотою, запамороченням, відчуттям втрати свідомості, прискореним і нерівним диханням, грудкою в горлі, тремтінням у тілі, пітливістю, онімінням, слабкістю в ногах тощо. Ці прояви можуть бути як при усвідомлюваній тривозі, так і при неусвідомлюваній $[11,12,19]$.

Тривога має природне походження, основна функція якої захистити життя. Вона може виникати в ситуації загрози власної безпеки, втрати автономії, втрати самоконтролю. Що стосується різних поглядів дослідників на зв'язок тривоги і страху, то більшість авторів схильні розглядати тривогу як реакцію на невизначений сигнал небезпеки, а страх - як конкретний сигнал про загрозу.

Наприклад, У. Мак Дугалл розмежовує поняття емоції страху і тривоги. На його думку, загальною рисою для тривоги $\epsilon$ не страх, а стан настороженості або готовності виконати будь-яку дію. Тривога являє собою досить складне утворення, в основі якого знаходиться комплекс таких емоцій, як надія, тривога, смуток, відчай. Співвідношення даних емоцій буде залежати від інтелектуальної оцінки ступеня перешкод між суб'єктом і його цілями $[16,24]$.

Інші автори воліють відзначати лише кількісні відмінності страху і тривоги. Так, якщо джерело тривоги не ліквідувати повністю, тривога переходить у страх. У рамках даної теорії, більшість досліджень показали, що тривога являє собою комплекс дискретних емоцій. Ключовим переживанням є страх, а другорядними - інші емоції, наприклад, смуток, сором, провина. 
Ч. Рікфорт у своїй праці «Тривога і неврози» розділяє тривогу передчуття і тривожне занепокоєння. Їх ріднять три аспекти: страх, невизначеність і передчуття. 3 точки зору автора, обидві форми занепокоєння є формами страху. Однак тривожне занепокоєння спрямоване на зовнішній об'єкт і схильне не провокувати уникнення, а зміну ситуації (Рикфорт, 2008) [35, 38, 39]. На його думку, почуття тривоги завжди невиправдане, а тривожне занепокоєння - виправдане. У цьому контексті аналізується поняття «понадтривожний», необхідне для проведення кордону між адекватним ситуації тривожним занепокоєнням i переживанням, поява якого зумовлена нерозкритим психологічним чинником $[5,19,20]$. Продовжуючи цю лінію, варто відзначити, що у працях багатьох авторів прийнято розділяти нормальну тривогу і невротичну. Суть невротичної тривоги полягає у відсутності небезпеки, що викликає іiі, у крайньому випадку - у невідповідності між дійсною небезпекою й інтенсивністю тривоги. Таким чином, небезпека, з якою стикається невротична особистість, може бути продуктом іiі уяви, тобто створена ії власними суб'єктивними факторами. 3 точки зору 3. Фрейда, небезпека може бути викликана інстинктивними джерелами, безпорадність виникає в результаті слабкості Я, його залежності від Воно і Понад-Я. У вузькому сенсі автор вважає невротичну тривогу страхом бути поглинутим інстинктивними домаганнями. 3 точки зору К. Хорні, тривога є реакцією на загрозу, насамперед, життєво важливих цінностей, і для різних пацієнтів відповідь буде різною. Наприклад, якщо «переважає потреба здаватися досконалим, безпека індивіда грунтується на відповідності своїм особливим стандартам або на те, що, на його думку, від нього очікують» $[12$, 36].

Ще одне поняття в рамках даної теми - це поняття тривожності, нерідко зустрічається у галузі психологічної діагностики. Під тривожністю в психології прийнято розуміти індивідуальну психологічну особливість, що має прояв у схильності людини до частих та сильних переживань, тривоги. Тривожність може розглядатися як особистісна особливість або як слабкість нервової системи, пов'язана з певним типом темпераменту.

Ч.Д. Спілбергер, досліджуючи тривожність як особистісну властивість і тривогу як стан, розділив ці два визначення на «реактивну» й «активну», «ситуативну» й «особистісну» тривожність. Стан тривоги або ситуативна тривожність виникають як реакція людини на різні, найчастіше соціально-психологічні стресори (очікування негативної оцінки або агресивної реакції, сприйняття негативного до себе ставлення, загрози своєї самоповаги, престижу). Навпаки, особистісна тривожність як риса дає уявлення про індивідуальні відмінності в схильності дії різних стресорів [16, 31].

Отже, мова йде про відносно стійку схильність людини сприймати загрозу своєму «Я» у найрізноманітніших ситуаціях і реагувати на ці ситуації підвищенням ситуативної тривожності. Величина особистісної тривожності характеризує минулий досвід індивіда, тобто, наскільки часто йому доводилося відчувати ситуативну тривожність (Батаршев, 2005).

Страх - це емоційний процес, який існує незалежно від культури та рівня народу чи його окремих представників. Змінюються лише об'єкти страху.Страх з'являється у ситуації, яка загрожує спокою та безпеці суб'єкта. Таким чином, страх, як і тривога завжди, є сигналом попередження про небезпеку. Страх почали вивчати досить давно [15]. Ще Аристотель і стоїки писали про страх, однак підходили до нього більше із філософської позиції. Страх також докладно вивчався багатьма релігіями. Із виділенням психології з суміжних наук як окремої наукової дисципліни страх став розглядатися в основному в контексті психологічної науки [1].

У теорії диференціальних емоцій К. Ізарда, страх віднесений до базових емоцій, $є$ уродженим емоційним процесом із генетично заданими певними мімічними проявами, фізіологічними механізмами і суб'єктивними переживаннями $[21,25]$. Фізіологічні прояви страху, на відміну від тривоги, головною метою мають мобілізацію всього організму для відповідної реакції на конкретну небезпеку і проявляються у вигляді м'язової напруги, посилення потовиділення, припливу крові до серця і скелетних м'язів, поверхневого дихання, тремору тощо. Абсолютно нормальними $\epsilon$ страхи, пов'язані із віковими змінами. Для більшості $з$ людей потенційна загроза фізичному стану не $\epsilon$ актуальною. Набагато частіше людей лякає те, що може вплинути на їхню зарозумілість, вразити гордість [10]. Як причину страху С. Томкінс називає драйви, емоції і когнітивні процеси. Коли драйв досягає критичного стану, він сигналізує організму про гострий фізіологічний дефіцит. Тоді він може активізувати емоції, однією 3 яких може бути страх[28]. Будь-яка емоція може активізувати страх за принципом зараження. Певні взаємозв'язки між емоціями можуть бути результатом навчання. Крім того, страх також може бути сам для себе активатором, це означає, що саме прояв страху може лякати людину. Найпоширенішими, 3 точки зору більшості авторів, активаторами страху можуть бути когнітивні процеси. Страх може бути результатом когнітивної оцінки ситуації як небезпечної [3, 29]. Серед природних активаторів страху автори виділяють: біль і антиципація, самотність, раптова зміна стимуляції. Будь-який об'єкт, подія або ситуація, пов'язані із переживанням болю, можуть у подальшому стати умовними стимулами, повторна зустріч з якими може активізувати почуття страху. Така ситуація як для тварин, так і для людини має адаптивний характер, оскільки дозволяє уникати хворобливих ситуацій без негативних для себе наслідків, іноді, навіть не відчуваючи страху перед болем [9]. 
Таким чином, один із способів навчання страху - це просте зумовлювання, механізм якого був описаний вище. Однак більшість людей, які страждають фобіями, не можуть пов'язати появи страху із якими-небудь певними травматичними подіями. Більш поширеною причиною появи страхів $є$ особлива форма навчання. Наприклад, спостереження дитини за реакцією страху в батьків дасть більше ймовірності того, що дитина буде боятися саме того, чого бояться батьки. Автори відзначають, що спостереження за емоційною експресією в ситуаціях загрози прискорює процес «запозичення» страху. Ще однією причиною появи страхів автори вважають нестійку прихильність до близьких для дитини людей (перш за все батька і матері). У період, коли закладаються основи особистості дитини, важливо, щоб батьки були поруч, були уважні до її потреб, внаслідок чого формується міцна прихильність до них. Це $є$ основою для почуттів ії безпеки та довіри $[22,26]$.

Д. Боулбі вважає, що діти зі сформованим почуттям прихильності, поки в них зберігається почуття довіри до об'єкта прихильності, менш сприйнятливі до страху. А основними факторами може бути загроза бути кинутим [4, 14]. Страх $є$ сильною емоцією, що помітно впливає на перцептивно-когнітивні процеси та поведінку людини. Сильний страх може створювати ефект «тунельного зору», що сильно звужує сприйняття, мислення і волю і, в кінцевому підсумку, поведінку людини. Основна мета поведінки в ситуації страху - це усунути джерело загрози. Якщо людина здатна сконцентрувати свою енергію і швидко усунути джерело загрози, то можна говорити про те, що обмеження сприйняття та поведінки виправдані і необхідні в даній ситуації. Оскільки страх є потенційно небезпечним переживанням, він має здатність відкладатися на потім [23, 27].

Бенджамін Колодзін, автор праці «Як жити після психічної травми», написав іiі для тих, хто шукає шляхи до зцілення і душевного спокою. Основою його праці став практичний досвід психотерапевтичної роботи із ветеранами війни у В'єтнамі і їх сім'ями, а також з особами, що перенесли сильні психічні потрясіння $[2,13]$. Перешкодою до формування психічного здоров'я, звільнення від психічної травми є позиція заперечення. На думку Б. Колодзіна «позиція самозаперечення - це самообман, який відбувається кожен раз, коли ми, з якоїсь причини, не бажаємо знати правди. Кажучи іншими словами, з усієї отриманої інформації ми обираємо лише те, що уміщається в зручний і звичний стереотип сприйняття. При цьому буває відкинуто практично все, що для нас ново і незвично ... а іноді і смішно» [2, 13].

Таким чином, спираючись на працю психотерапевта і його висновки, можна виявити один із критеріїв психічного нездоров'я, який є пограничним, перехідним - наявність позиції заперечення. Це заперечення нових ідей, нових знань, но- вин, поганих чи хороших, наукових даних, що не укладаються уже в напрацьованій теорії, події та факти, а також гумор і сатиру, які роблять смішними ці спотворення, живлячи натхнення гумористів і сатириків. На думку Б. Колодзіна, якщо «деякі відомі факти незмінно викликають в оточуючих почуття незручності, людина поступово вчиться ігнорувати цю частину свого досвіду, своєї особистості. Здається, що досвід не має ніякої цінності, що краще б взагалі цього не знати». Зрозуміло, що це заперечення існує з метою захистити себе від душевного болю або від фізичної небезпеки, в одній ситуації рятує життя, а в іншій - викликає масу неприємностей [4].

Зупинимося дещо на теорії страху в психоаналітичній концепції. Розвиток уявлень про теорію страху в психоаналізі, у першу чергу, варто віднести до робіт Зігмунда Фрейда. Тривалий час ця проблема розглядалася в рамках відносно простої концепції, остаточне формулювання з'явилося набагато пізніше i, головним чином, представлена в більш пізній праці «Гальмування, симптом і страх» $[12,40] .3$ точки зору першої теорії, страх з'являється як у дитини, так і в дорослого саме тоді, коли лібідо не може досягти свого задоволення. Діти з раннім або надмірним сексуальним потягом більшою мірою схильні до страху. Однак варто розрізняти реальний страх і невротичний. Реальний страх запускається сприйняттям зовнішньої небезпеки і пов'язаний із реакцією самозбереження. Невротичний страх може характеризуватися реакцією захисту без реального існування страху, але будучи дуже сильним, може паралізувати суб'єкт. Страху такій ситуації не відповідає жодній меті. Таким чином, 3. Фрейд також вказує на ірраціональність невротичних страхів, що співвідносно із класичним розумінням сутності фобій $[11,24,26]$. Друга, більш пізня концепція, призвела до значних змін. Тепер страх не $\epsilon$ автоматично результатом, пов'язаним із витісненням, швидше сам страх здійснює витіснення. Невротичний страх стає близьким до страху перед реальною небезпекою, якщо суб'єкт так іiї оцінює. Страх не з'являється щоразу як нове явище, він відтворюється у вигляді емоційного стану як вже існуючий слід у пам'яті. 3 точки зору автора, обсесивний невроз відрізняється від фобії тим, що в першому випадку ситуація небезпеки утворюється через ворожість Понад-Я, то $\epsilon$ небезпека, що не проектується зовні, вона $є$ інтеріорізованою. Страх у будь-якому випадку пов'язаний із розгубленістю перед небезпекою. Травматична ситуація, пов'язана із реально пережитою небезпекою, підводить до думки існування мимовільного, автоматичного страху. Небезпечна ситуація, що нагадує травматичну, дає можливість підготуватися до неї, і тоді можна говорити про сигнальний страх. Надалі 3.Фрейд виділив обсесії та фобії від неврастенії. Також автор провів паралель між фобічними проявами і неврозом страху, обсесивними проявами та фобічними неврозами [12]. 
Ф. Ріман у своїй праці «Основні форми страху» зазначає, що всі можливі варіанти страху зводяться в кінцевому підсумку до чотирьох варіантів і пов'язані із чотирма основними імпульсами, які трапляються попарно і доповнюють один одного або суперечать один одному (Ріман, 1999) $[6,25,29]$. Прагнення до самозбереження і самоєднання із протилежним прагненням до самовіддачі, як прагнення до стабільності і безпеки із протилежним прагненням до змін і ризиків. 3 точки зору Ф. Рімана, основні форми страху, які $є$ в житті кожної людини, такі: 1. Страх перед самозреченням, пережитий як втрата Я і залежність. У цьому ракурсі автор описує шизоїдних особистостей зі страхом перед самовіддачею, близькістю в міжособистісних відносинах, що $\epsilon$ загрозою існування. 2. Страх перед самовідновленням (стагнація), пережитий як беззахисність та ізоляція. У цьому контексті часто трапляється страх перед становленням Я, перед індивідуалізацією, страх самотності. Тут автор наводить приклад депресивних особистостей, для яких безпека - це, насамперед, залежність. 3.Страх перед змінами, який переживається як відчуття мінливості i невпевненості. Подібний механізм можна спостерігати в осіб із нав'язливими думками, які бояться змін, свободи, ризику, із патологічним бажанням залишити все як і раніше. 4. Страх перед необхідністю, який переживається як відчуття остаточності і несвободи. Страх перед остаточністю в основному трапляється в осіб із істеричними рисами, що має прояв як уникнення різного роду обмежень і прагнення до змін, свободи, жадоби до всього нового і ризикованого [6]. Ці невротичні страхи виконують функцію заміщення та знешкодження, разом 3 тим, вони карикатурно спотворюють основний страх існування. Ці страхи є важливим чинником розвитку. Подолавши страх, людина висуває нові вимоги до життя, ухилення від боротьби зі страхом - це поразка, яка вражає й ослаблює людину. Сильні напади страху можуть бути початком психозу, депресії або при меншому вираженні неврозу. Також може означати початок психосоматичного розладу [7]. У найближчому зв'язку із «неврозом страху» знаходиться фобічний невроз. Тут на першому місці перебуває тривога і страх, які мають конкретну причину. Дуже часто причина є дивною i невинною, що в інших людей не викликає жодного побоювання. Незважаючи на те, що деякі причини i об'єктивно можуть викликати страх (наприклад, висота, деякі тварини тощо), але в разі фобічного неврозу цей страх болісно посилюється і стає неадекватним. Невротична фобія відрізняється від інших видів страху (які можуть бути симптомами серйозних психічних захворювань) тим, що пацієнт повністю усвідомлює безглуздість цих страхів.

Найбільш поширеним фобічним неврозом $є$ обсесивний невроз. Клінічна картина представлена відсутністю афективності: холодність поведінки, відсутність емоційності, думка заміщує дії, спостерігається майже повне зникнення спонтанності. Друга сторона симптоматики - це нав'язливий контроль. При цьому треба виключити такі загальноприйняті феномени нав'язливого контролю, як сексуальна нав'язливість та ідея фікс. Обсесивний характер включає такі особливості, як педантичність, акуратність, скупість, упертість, встановлення по відношенню до афективних об'єкту дистанції. Втрата нав'язливого контролю зовні може мати прояв у вигляді агресії [7]. У класичному розумінні більш інтенсивні, ірраціональні страхи, пов'язані з певними об'єктами та ситуаціями, отримали назву фобіі. Більшість авторів сходяться на думці, що фобії мають набутий характер. Однак $є$ розбіжності серед авторів щодо того, що фобії є умовно емоційними реакціями або мають все-таки біологічні передумови реагувати емоцією страху на певні стимули.

С. Джейкобе i Л. Нейдел описують кілька специфічних особливостей фобій. Основні 3 них можна позначити як спонтанні, які виникають часто без видимих причин (люди не можуть згадати, коли лякаючий об'єкт реально заподіяв шкоду). Поява страху або фобії відбувається без будьякого видимого зв'язку із контекстом ситуації або зі специфічною подією, часто страхи не зникають, навіть після багаторазового зіткнення із лякаючим об'єктом, навіть якщо він не завдає шкоди. Однак Р. Макноллі висловив незгоду 3 даною точкою зору, оскільки, за його спостереженнями, наприклад, агорафобія зазвичай прив'язана до конкретної ситуації. Також автор зазначає, що оскільки люди 3 фобіями виробляють стратегію уникнення травмуючих ситуацій, лякаючий об'єкт зберігає свою силу. Тому тривале існування фобій швидше може пояснюватися браком досвіду реальних зіткнень із лякаючим об'єктом, ніж нездатністю 3 ним впоратися $[8,23,24]$.

Сором посідає важливе місце в людських відносинах, але вивчений він набагато менше, ніж інші емоції. Тісний зв'язок сорому зі страхом, провиною, збентеженням, відчуттям приниження, а також гелотофобією (страхом здаватися об'єктом глузування) підводить до думки про необхідність розгляду даної емоційної категорії в рамках огляду літератури даної роботи. Часто сором, збентеження i провину розглядають як прояви однієї і тієї ж емоції, іноді як абсолютно різні емоції, іноді як різні емоції, що мають деякі загальні риси. Ч. Дарвін відносив сором, збентеження, провину до однієї групи емоцій - групи «сорому», однак виділяв індивідуальні відмінності кожного з цих проявів $[27,28]$. Мімічні та фізіологічні прояви сорому схожі на прояви збентеження. Коли людина відчуває сором, вона може опускати очі, відвертатися, опускати голову, всім тілом прагнути стати меншою і більш непомітною, може виникати червоний рум'янець на обличчі. Подальші дослідження показали, що рум'янець може контролюватися і не проявляти себе $[27,28]$. Сором і провина притаманні всім людям й архетипічно закладені в особистості. У психоа- 
налітичних колах тривалий час переважала впевненість у схожості понять провини і сорому, що призвело до постулювання залежності як провини, так і від сорому взаємин Его і Супер-Его. Дійсно, ці феномени часто з'являються одночасно, однак $є$ відмінності. Почуття провини відбувається від етичних і моральних норм, званих у філософії «непорушними законами», і виникає як результат установки «я залишаюся в боргу перед деякими зобов'язаннями». Поняття сорому етимологи пов'язують із німецьким корінням «кам/ kem», що позначає «приховувати», «покривати». Ідея прикривати себе яким-небудь убранням довгий час здавалася основною складовою поняття сором. Пізніше сором став використовуватися при позначенні статевих органів - «таємних місць». Сором часто був пов'язаний із ганьбою i використовувався для позначення безчестя.

Антрополог Р. Бенедикт слідом за 3. Фрейдом пояснює провину як внутрішню критику, а сором - як реакцію на критику ззовні. Сором - це почуття, коли тебе бачать поганим, спостерігач у цьому випадку знаходиться поза власним «Я». Провина формується почуттям активної можливості здійснення зла, тоді як сором має ще й значення безпорадності та потворності $[10,30]$.

X. Льюїс та іï колеги вважають, що переживання сорому базуються на «зразку знань про себе». Для того, щоб дитина навчилася відчувати сором, вона повинна навчитися взаєминам із самою собою. У неї повинен сформуватися ясний образ «Я», з яким треба навчитися свідомо співвідносити себе. Також автор зазначає, що переживання сорому можливо лише на тлі емоційних відносин із людиною, такою, чия думка має особливу цінність.

На перший погляд, сором є виключно дезадаптивною емоцією, однак ряд авторів підкреслюють неоднозначність ролі сорому для людини залежно від здатності людини з ним справлятися. С. Томкінс описує сором як емоцію найвищої рефлексії, коли стирається грань між суб'єктом і об'єктом сорому, і людина занурюється в болісне самопізнання [4, 28, 29].

Хелен Льюіс зазначає, що люди пережили сором, відчувають себе вкрай смішними, приниженими. Говорячи про позитивні функції сорому для людини, варто відзначити, насамперед, те, що переживання сорому підвищує сенситивність людини до почуттів й оцінок оточуючих, сприяючи таким чином згуртованості. По-друге, сором відіграє важливу роль у становленні інституту шлюбу, сприяє зменшенню конфліктів між представниками різних статей, більшій нетерпимості до фізичної агресії з боку чоловіків. По-третє, під впливом сорому виявляються нерозвиненими, незахищеними знаннями про аспекти «Я» [24, 27].

К.Е. Ізард виділяє декілька механізмів, що дозволяють уникати почуття сорому. Одним із них $є$ заперечення. Заперечення самого існування або значущості джерела сорому може стати одним із способів досягнення цієї мети. Іншим ме- ханізмом може бути придушення. Третім способом боротьби із соромом може бути самоствердження. Ганебна ситуація в такому випадку викличе потребу в самоствердженні, і зовсім не обов'язково стосується рис особистості, які були об'єктом сорому. Більш радикальним способом захисту «Я» від сорому вважається депресія [4, 31, 33].

Таким чином, незважаючи на те, що вперше феномен гелотофобії виявлений на клінічному матеріалі, у подальшому більшість досліджень страху виглядати смішним, проводилися на здорових випробовуваних, i феномен гелотофобії розглядається в контексті психології індивідуальних відмінностей. Таким чином, виникло дві різних, хоча й пересічних, концепції досліджень гелотофобії: 1) гелотофобія в клінічному контексті як форма соціофобії; 2) гелотофобія як феномен індивідуальних відмінностей $[34,35]$. нціаціiі:

В. Рух пропонує наступні критерії дифере-

1. Безпідставність страху виглядати смішним (страх не має реальної причини). Розрізняють «реалістичних» і «чистих» людей, які страждають гелотофобією. Перші дійсно часто піддавалися глузуванням із боку оточуючих з будь-яких причин, тобто їх страх має підстави, він $є$ реалістичним. У другому випадку, люди рідко піддавалися глузуванням, тим не менш, у них сформувався страх виглядати смішним. Оскільки цей страх не має достатніх реалістичних підстав, він може розглядатися як патологічний.

2. Фізіологічні та поведінкові симптоми мають екстраординарну інтенсивність, що оцінюється за допомогою спеціально розробленого В.Рухом і Т. Платтом структурного інтерв'ю.

3. Страх, що зберігається тривалий час, частково оцінюється опитувальником гелотофобіі, оскільки ряд тверджень стосується того, наскільки легко людині відновитися після пережитого глузування.

У рамках концепції індивідуальних відмінностей у лабораторії В.Руху проведено два дослідження, основною метою яких було виявлення особливостей почуття гумору людей із високим рівнем гелотофобії, а саме, досліджувалося питання щодо змісту їхнього гумору в цілому та окремих його компонентів. Дослідження показали, що люди із високою гелотофобією $є$ менш веселими, ніж інші, характеризують своє почуття гумору як недоречне, соціально холодне, навіть підле. 3 іншого боку, дотепність, здатність творити гумор, виявилися не пов'язаними із гелотофобією, тобто здатність жартувати в цих людей не знижена [35].

Дослідження Т. Платт показали, що люди із високим рівнем гелотофобії не розрізняють добродушних жартів й дійсно агресивного глузування [22]. Якщо добродушний сміх у нормі викликає позитивні емоції, то люди з високою гелотофобією сприймають будь-який сміх на свою адресу як загрозливий. 
Таким чином, можна дійти висновку, що гелотофобія розвивається на основі страху, тривоги, почуття сорому та провини. Перші предиктори гелотофобії закладаються ще в дитинстві, коли важливу роль для дитини мають відношення до неї батьків та мікро- і макросоціуму, в якому дитина проходить процес становлення.

У дорослому віці ці патерни поглиблюються і викликають ряд психосоматичних розладів.

Гелотофобія на даний час, $є$ актуальною як соціальна проблема, оскільки людині $з$ проявами гелотофобії тяжко соціалізуватися, налагоджувати комунікативні зв'язки, трудові та сімейні відносини. Тому дуже важливим $є$ виявлення проявів гелотофобії на ранніх стадіях (у дитячому віці), щоб запобігти багатьом проблемам соціального та психологічного характеру. Гумор у цьому випадку стає інструментом діагностики гелотофобіï, іiі психокорекції і терапії. Ці положення мають стати перспективою дослідження порушення психічної діяльності людини.

\section{Література}

1. Аристотель. Поэтика. Риторика / Аристотель. - СПб.: Изд-во Азбука, 2000. - 119 с.

2. Взаимосвязь изменений разных уровней организации личности при остром стрессе / [Кузнецова Т.Г., Горбачева М.В., Буркова С.А., Булгакова О.С.]. - Фундамент. исследования. - 2015. - № 12 (часть 1). - С. 192196

3. Котро Ж. Когнитивная терапия фобий / Ж. Котро, Е. Моллар // Москов. Психотерапевт. ж. - 1996. - № 3. - C. 93-111.

4. Лурия А.Р. Высшие корковые функции человека / Лурия А.Р. - М.: изд-во МГУ, 2000. - 432 с.

5. Рикфорт Ч. Тревога и неврозы / Ч. Рикфорт; пер. с англ. В.М. Астапов, Ю.М. Кузнецова / Под ред. В.М. Астапова. - М.: ПЕР СЭ, 2008. - 142 с.

6. Риман Ф. Основные формы страха / Ф. Риман; пер. с нем. Э.Л. Гушанского. - М.: Алетейа, 1999. - 336 с.

7. Рубинштейн С.Л. Основы общей психологии в 2-х томах. - СПб.: Питер, 2000. - Т. 2. - 328 с.

8. Социальная фобия. Карманный справочник / Под ред. С.А. Монтгомери. - Базель, Швейцария: Ф. Хоффманн. - Ля Рош, 1995. - 52 с.

9. Симонов П.В. Темперамент. Характер. Личность. / П.В. Симонов, П.М. Ершов. - М.: Наука, 2002. - 161 с.

10. Стефаненко Е.А. Гелотофобия как расстройство совладающего поведения / Е.А. Стефаненко / Психология совладающего поведения: материалы междунар. науч.-практ. конф. - Кострома: КГУ имени Н.А. Некрасова, - 2007. - С. 360-361.

11. Фрейд 3. Остроумие и его отношение к бессознательному / Фрейд 3. - М.: АСТ; Мн.: Харвест, 2006. $480 \mathrm{c}$.

12. Фрейд 3. Художник и функционирование / Фрейд 3. М.: Республика, 2003. - 200c.

13. Фенихель О. Психоаналитическая теория неврозов / О. Фенихель / Пер. с англ., вступ. ст. А.Б. Хавина. 2-е изд. - М.: Академический Проект, 2005. - 848 с.

14. Хекхаузен Х. Мотивация и деятельность / Х. Хекхаузен. 2-е изд. - СПб.: Питер, 2003. - 860 с.

15. Хорни К. Тревожность: собр. соч. в 3-х томах. Т. 2 / К. Хорни. - М.: Смысл, 1997. - Т. 2. - С. 174-180

16. Хилл Н. Ключ к успеху / Хилл Н. - Минск, 2006. $640 \mathrm{c}$.

17. Шмелев А.Г. Юмор - это не главное / А.Г. Шмелев // Психол. газета. - 2000. - № 4 (31). - С. 24-25.

18. Шнайдер К. Клиническая психопатология / К. Шнайдер. - М.: Сфера, 1999. - 236 с.
19. Якоби М. Стыд и истоки самоуважения / М. Якоби. М.: Институт Аналитической Психологии, 2001. $251 \mathrm{c}$.

20. Adams P. Gesundheit: Bringing good health to you, the medical system, and society though physicianservice, complementary therapies, humor, and joy Rochester P. Adams, M. Mylander. - Vermont: Healing Arts Press, 1986. -227 p.

21. Beitman B.D. Pharmacotherapy as an intervention during the stages of psychotherapy / B.D. Beitman // Am. J. of Psychotherapy. - 1981. - Vol. 35, № 2. - P. 206-214.

22. Edwards K.R. The fear of being laughed at, social anxiety, and memories of being teased during childhood K.R. Edwards, R.A. Martin, D.J.A. Dozois // Psychological Test and Assessment Modeling. - 2010. - Vol. 52. P. 94-107.

23. Erikson E.H. Childhood and Society / E.H. Erikson. New York: Norton, 1993. $-445 \mathrm{p}$.

24. Falkenberg I. Sense of humor in patients with schizophrenia / I. Falkenberg K. Klu gel M. Bartels, B. Wild // Schizophrenia Research. - 2007. - Vol. 95. - P. 259-261.

25. Forabosco G. The ill side of humor: Pathological conditions and sense of humor. The Sense of Humor: explorations of a personality characteristic / G. Forabosco. N.Y.: Mouton de Gruyter, 2007. - P. 271-292.

26. House A. Anxiety in medical patients ABC of psychological medicine (Clinical review) / A. House, D. Stark // British Medical J. - 2002. - Vol. 325. - P. 207-209.

27. Individual differences in uses of humor and their relation to psychological well-being: Development of the Humor Styles Questionnaire / R.A. Martin, P. Puhlik-Doris, G. Larsen [et al.] // Journal of Research in Personality. 2003. - № 37. - P. 48-75.

28. Lifetime co-morbidities between social phobia and mood disorders in the US National Comorbidity Survey / R.C. Kessler, P. Stang, H.U. Wittchen [et al.] // Psychological Medicine. - 1999. - Vol. 29. - P. 555-567.

29. Kretschmer E. Der sensitive Beziehungswahn / E. Kretschmer. - Berlin - Heidelberg - New-York: 4. Aufl. Springer, 1966. $-272 \mathrm{p}$.

30. Lange A. A self-regulatory perspective on the effects of humor styles in relation to burnout and work engagement [Электронный ресурс] / A. Lange, J. Dikkers, E. Demerouti // URL: http://www.uv.es/unipsico /Noticias/ pdf $/ 002$ Conference Programme.pdf

31. Levine $\bar{J}$., Abelson R. Humor as a Disturbing Stimulus / Levine J. (ed.) Motivation in Humor. - New York: Atherton Press, 1969. $-35 \mathrm{p}$.

32. Lampert M.D. Cross-cultural variation in gelotophobia within the United States / M.D. Lampert, K.L. Isaacso, J. Lyttle // Psychological Test and Assessment Modeling. 2010. -Vol. 52 (2). - P. 202-216.

33. Proyer R.T. An Initial Study on How Families Deal with Ridicule and Being Laughed at: Parenting Styles and Parent-Child Relations with Respect to Gelotophobia, Gelotophilia, and Katagelasticism / R.T. Proyer, S. Estoppey, W. Ruch // Journal of Adult Development. - 2012. Vol.19, № 4. - P. 228-237.

34. Ruch W. Gelotophobia - fear of being laughed at: A useful new concept? / W. Ruch // IPSR. - Spring. - 2004. Colloquium Series (manuscript unpublished).

35. Ruch W. // International Journal of Humor Research / W. Ruch, R.T. Proyer. - 2008. - № 21 (1). - P. 47-67.

36. Ryle A. Psychotherapy: a cognitive integration of theory and practice / A. Ryle. - London: Academic Press, 1982. $-396 \mathrm{p}$.

37. Titze M. Die heilende Kraft des Lachens [The Healing Power of Laughter] / M. Titze. - Munich, Germany: Kösel, 2004. $-367 \mathrm{p}$.

38. Vollrath M. Differential effects of coping in mental disorders: A prospective study in psychiatric outpatients M. Vollrath, P. Alnaes, S. Torgersen // J. of Clinical Psychology. - 1998. - Vol. 52, № 2. - P. 125-135. 
39. Walen S.R. A practitioner's guide to rational-emotive therapy / S.R. Walen, R. DiGiuseppe, W. Dryden. - New York: Oxford Uniersity Press, 1992. -218 p.
40. Westwood R. Humor in organization: From function to resistance / R. Westwood, A. Johnston // Humor. - 2013. - № 26 (2). - P. 219-247.

\section{ГЕЛОТОФОБИЯ КАК ПСИХОЛОГИЧЕСКАЯ ПРОБЛЕМА ОБЩЕСТВА И ФОРМА СОЦИОФОБИИ (ОБЗОР ЛИТЕРАТУРЫ)}

\section{O.H. Шиортун}

Резюме. В статье анализируется особая форма социофобии - гелотофобия (страх быть осмеянным) - психическое расстройство невротического спектра по типу социофобии. Установлено, что эмоциональными паттернами гелотофобии есть страх, тревога, стыд, чувство вины и т. Общими показателями являются: наличие выраженного страха типа социальных ситуаций (ситуации насмешки), преобладание тревоги в определенных ситуациях, выраженность психофизиологических симптомов тревоги, низкая самооценка и страх критики, эмоциональное переживание, осознание того, что страх не обоснован, избегание потенциально опасных ситуаций, в своих крайних проявлениях приводит к социальной изоляции.

Ключевые слова: гелотофобия, социофобия, страх, невротическая личность.

\section{GELOTOPHOBIA AS A PSYCHOLOGICAL PROBLEM OF SOCIETY AND FORM OF SOCIOPHOBIA (REVIEW OF THE REFERENCES)}

\section{O.N. Shportun}

Abstract. The article analyzes a particular form of sociophobia - gelotophobia (fear of gibe) - a mental disorder of neurotic spectrum of the type of sociophobia. It was found that the emotional patterns of gelotophobia are fear, anxiety, shame, guilt, and so on. The common indicators are: the presence of the expressed fear of the type of social situations (situations of gibe), the prevalence of anxiety in certain situations, the evidence of psychophysiological symptoms of anxiety, low self-appraisal and fear of criticism, emotional experience, perception that fear is not valid, avoidance of potential dangerous situations in extreme cases leads to social isolation.

Key words: gelotophobia, sociophobia, anxiety, neurotic personality.

Taras Shevchenko National University (Kyiv)

Рецензент - проф. А.С. Борисюк
Buk. Med. Herald. - 2016. - Vol. 20, № 1 (77). - P. 228-235

Надійшла до редакції 26.01.2016 року

(C) O.М. Шпортун, 2016 